\title{
The Influence of Marketing Factors on the Marketing Strategic Planning in SNOWA Corporation
}

\author{
Ali Ebrahimi Ghahnavieh ${ }^{1}$ \\ ${ }^{1}$ Entekhab Industrial Group/Marketing Department, Amini Alley, Sabalanst, Tehran, Iran \\ Correspondence: Ali Ebrahimi Ghahnavieh, Entekhab Industrial Group/ Marketing Department, Amini Alley, \\ Sabalanst, Tehran, Iran.
}

Received: March 26, 2018

doi:10.11114/bms.v4i4.3133

\author{
Accepted: April 10, $2018 \quad$ Online Published: December 11, 2018
}

URL: https://doi.org/10.11114/bms.v4i4.3133

\begin{abstract}
The purpose of this research is to evaluate the influence of marketing factors of SNOWA Corporation on its marketing strategic planning. The present study is an applied research using a descriptive-analytic method. The statistical sample of this research includes 300 personnel of SNOWA Corporation. Data were collected applying a standard questionnaire on a five-point Likert scale. CVR and CVI indices were used to evaluate the content validity of the questionnaire, and a Cronbach's Alpha Test was applied to assess its reliability. SPSS Software (factor analysis) and Amos Software (structural equation modelling) were applied to analyse the collected data. The study will help managers accomplish market opportunities efficiently while formulating corporation strategies. Findings further reveal that consideration of marketing factors can give managers valuable information that, if applied correctly, can effectively guarantee corporation's success.
\end{abstract}

Keywords: marketing, marketing plan, marketing strategic planning

\section{Introduction}

The purpose of this research is to evaluate the influence of marketing factors of SNOWA Corporation on its marketing strategic planning. The focus of this study is to identify the role of marketing factors on marketing strategy formulation. Besides, this study was conducted under economic sanctions. In this study, we are looking to answer the following questions. What is the influence of marketing factors on marketing strategic planning? And how Strong is that? What marketing factors affecting the company?

Marketing strategies are so important these days for each company. Nowadays, the business world is changing constantly. To decrease environmental pressures, successful companies have to pay a careful attention to three important subjects which includes the expansion of globalization, development of modern technologies and economic turmoil (Petersen, 2015). A review of the major prescriptive literature about the marketing strategic planning (Anderson, 1982) (Aaker, 2010) (Cravens, 2006) (Perreault, 2011) shows that the following marketing factors influence marketing strategic planning either implicitly or explicitly: Identify and Select the Target Market; Marketing Mix; Marketing Plan. A target market is a particular group of consumers at which a product or service is aimed (Levy, 2012). The Marketing Mix is a combination of factors that can be controlled by a company to influence consumers to purchase its products (Huang, 2014). A marketing plan is a business's operational document for outreach and advertising to generate leads and reach its target market (Westwood, 2013). Among the factors affecting marketing strategic management, marketing factors selected in order to evaluate their effectiveness. There is little research has been done to examine the effectiveness of these factors in the current economic sanctions.

Marketing helps corporations develop products and services in its business that meet the needs of your target market. Good marketing helps customers understand why your product or service is better than, or different from, the competition (Burns, 2014). Marketing strategies created by marketing managers that help companies meet their sales objectives. They conduct research, evaluate product demand, establish pricing strategies, identify a target audience, and determine the best way to reach that audience (Lantos, 2015). The aim is to contribute to the existing theory on marketing strategic planning by providing further insights into the Identify and Select the Target Market; Marketing Mix; Marketing Plan. Whether a company is small or large, marketing strategic planning plays an important role in decisions about which products or services should offer and how to sell them. The following research questions will be 
addressed: What affect the growth of the company? Who are the leaders? What type of marketing strategy is usually used? How many competitors exist there? How much market share they have? What type of product is offered in the industry? The answers to these questions are important to managers in order to figure out which action should be done. By answering these questions, not only companies could respond to market changes, but also they could be the source of creativity and excel rather than competitors.

A lack of proper marketing activities in organizations will make top managers not have the ability to decide about market's circumstance agile. As well, without marketing, potential customers will never know about your business. This is why companies have to SHOUT about their business and get the brand out there. The more you let people know about you, the more people will start to remember you (Martin, 2013). As the theoretical topics in this research are directly related to the current and actual conditions in Iranian corporations, this research may offer viable solutions from which corporations can benefit.

This paper has the following structure. First it will draw on three strands of theoretical background: The STP analysis; The Marketing Mix; The Marketing Plan. Together, these three areas provide the theoretical rationale for this study. In the following, a conceptual model and hypotheses were presented. The choice of the petrochemical industry as a suitable context for this study is then presented and a research methodology proposed. After preparation of the self-made questionnaire and verified by the experts of this field, they were distributed among the statistical population. The data analysed by SPSS and LISREL. In the implementation section, the model was applied in the SNOWA corporation. In the end, a discussion on the findings, implications for managers, limitations and future research concludes this paper.

\section{Theoretical Background}

Various studies have been conducted on the impact of marketing factors on organizational strategies, but these studies have been conducted in countries that have not been affected by international sanctions. In this study, we have tried to explain the different methods and models used by researchers. In the following, we examine the results of these methods on marketing strategic management. (Anderson, 1982) believes that marketing factors have a positive effect on the goal setting and process of strategic planning. (Cravens, 2006) reached conclusion that marketing factors and interrelations help to better corporate strategy formulation. (Andreasen, 2008) also concluded that there is a significant relationship between marketing factors and success in strategy formulation. (Proctor, 2014) concluded in their study that the impact of marketing factors on corporate strategies had a modest effect. (McDONALD, 2016) believe that companies should be active in dealing with different market and corporate strategies should be appropriate to the customer's need. In the following paragraphs, I categorized marketing factors into three divisions:

\subsection{Marketing Definition}

Marketing is an exchange relationship: a process providing mutual benefit to both parties in the transaction. It is an evolving process, one that is influenced by the definitions, perceptions, environmental \& cultural conditions \& trends. In the past, the concept of "selling" defined marketing; this has now changed dramatically (Fernando, 2012).

\subsection{STP Analysis}

(Perreault, 2011) examined the impact of marketing factors on the performance of companies by using of STP analysis, which resulted in a positive result. Also, (Varadarajan, 2010) prove that the impact of marketing factors on the performance of the company and their strategies are modest. In this study, the STP analysis is applied. STP analysis stands for segmentation, targeting and positioning, it is one of the most strategic approaches used in modern marketing. In terms of STP essence, market segmentation is the process of identifying a segment from a board consumer, which based on the differences in customer needs. A target market is an essential step that a company has decided to select a customer group in which they are the most favourable market for business. Finally, Product positioning is what comes to the customers' minds when they think about the business (Tanner, 2015). In the following paragraph, three part of this model will elaborate in depth.

1) Segmentation: Segmentation, or it is very often called market segmentation. It may refer to divide the market into smaller segments. A market segment is a group of customers who may buy products $\mathrm{f}$ a company. The four basic market segments may include: Geographical criteria (global, national, state, region, city, town, climate), Demographical criteria (gender, age, education, income, religion, class), Psycho-graphical criteria (personality, lifestyle, values), Behavioural criteria (usage rate, loyalty level, key benefits) (Kotler, 2010).

2) Targeting: To focus on the target market, or target group. That is perhaps targeting. Target market may express a set of customers sharing common characteristics and needs of a company (Kotler, 2010). The best actions and plans are probably served for the target segment (West, 2015). 
3) Positioning. Positioning is the third item of STP. It is probably the process of how customers perceive a company, or how products come to the minds of target customers (Kotler, 2010). The aim of positioning is perhaps to ensure a clear and a different image in the minds of all customers. The image must be positive and consistent. Positioning might start before the first customer visit the store (Muhamad, 2012).

\subsection{Marketing Mix}

(Patil, 2017) concluded that an effective marketing mix requires the deployment of several interconnected components, commonly referred to as the marketing mix or the marketing 4 Ps: product, place, price and promotion. In the 1950s, the marketing mix was introduced in the United States. It consists of 4 parts and all the parts might cooperate with each other. The four-parts are: product, price, place and promotion (Hill, 2012).

This marketing mix consists of tools that are suitable to implement the marketing strategy and may also serve as an approach to study marketing in networks. An appropriate marketing mix plays an important role in the realization of marketing strategies and it can also increase the sales and profitability of the firm. The marketing mix is a combination of factors that can be controlled by a company to influence consumers to purchase its products (Haugum, 2017). In the following paragraph, four-part of this model will explain in depth.

1) Price: It is the most flexible element of e-marketing comparing to other three elements of the marketing mix, since it can be changed quickly to adapt to the market's demand.

2) Place: This $P$ of the marketing mix is related to physical distribution of goods. it is concerned with middleman and place where the goods should be displayed and made available to the potential buyers.

3) Promotion: It is one of four variables in the marketing mix. Promotion is the activities, which are taken up in marketing to sell product and services. It refers to how marketing communications are used to inform customers and other stakeholders about the company and its product.

4) Products: It is a solution to customers wants and needs. It refers to the characteristics of a product, service or brand. A product is a benefit or service, which a business provides to its customers.

The marketing mix idea has two main benefits. First, it is a tool used to enable one to see that the marketing manager's job is trading off the benefits of one's competitive strengths in the marketing mix versus the benefits of others. The second advantage of the marketing mix is that it helps to show another dimension of the marketing manager's job. All managers have to allocate scarce resources among various demands, and the marketing manager will in turn allocate these resources among the different competitive activities of the marketing mix (Londhe, 2014).

\subsection{Marketing Plan}

(Aaker, 2010) concluded that the marketing plan is the base of a well-designed marketing strategic planning. While a marketing strategic planning includes a lot of actions, if it doesn't have a good marketing plan is useless. Today marketing has become a crucial part of a business' strategy in order to grow in an ever-treacherous business environment. Marketing practices have become active and thus the creation and implementation of a marketing plan should be dynamic and constantly reviewed over time.

marketing planning could be defined as a structured process that leads to a coordinated set of marketing decisions and actions, for a specific period, based on an analysis of the current internal and external situation, including markets and customers, a clear marketing direction, objectives, strategies and programs for targeted customer segments, support through customer service and internal marketing programs and management of marketing activities through implementation, evaluation and control. (Wood, 2010) A successful marketing plan should strive to explain the intended strategies for building relationships by creating, communicating, and delivering value to customers.

\section{Method}

\subsection{Conceptual Model}

Establishing a theoretical foundation is the first step toward proposing a conceptual framework. Setting up a theoretical foundation involves theory verification that is confirmatory in nature or theory building that is exploratory in nature (Kumar, 2016). The present study is confirmatory as well as descriptive in nature. Due to the importance of marketing strategic planning for every company in the world of business, this research will investigate the influence of "Identify and select the target market" and "Marketing Mix" and "Marketing Plan" on "Marketing strategic planning" in SNOWA Corporation. The proposed conceptual model is presented as follows: 


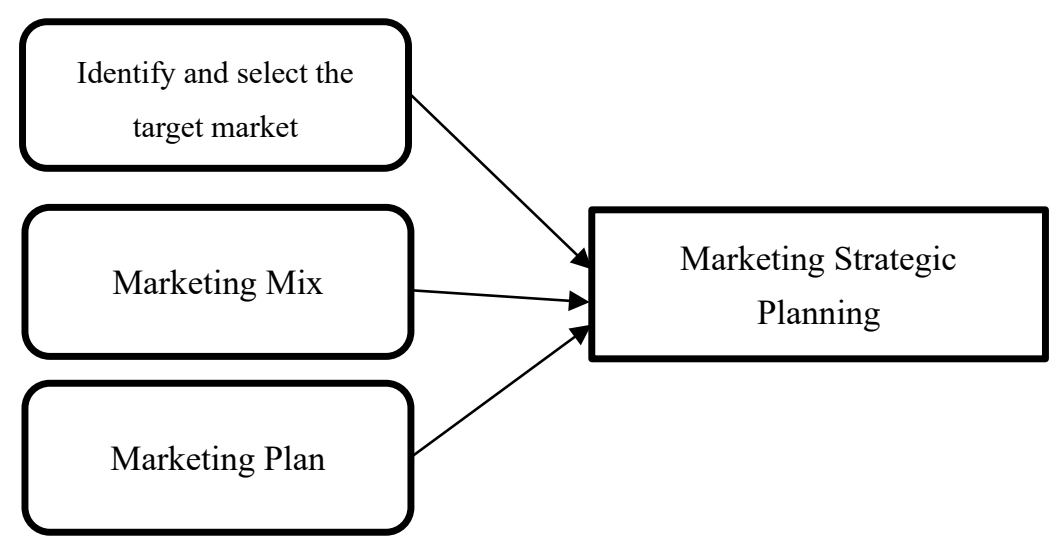

\subsection{Hypotheses}

Figure 1. Conceptual model

Considering the essence and the subject of this research, two hypotheses are considered as follows:

Hypothesis 1: There is an important relationship between "Identify and select the target market" and "Marketing strategic planning".

Hypothesis 2: There is an important relationship between "Marketing Mix" and "Marketing strategic planning".

Hypothesis 3: There is an important relationship between "Marketing Plan" and "Marketing strategic planning".

\subsection{Research Methodology}

The purpose of this research is to evaluate the influence of strategy formulation factor of SNOWA Corporation on its marketing strategic planning. The current study is an practical research using a descriptive analytic method. The statistical sample of this research consists of 300 personnel of SNOWA Corporation. Data were collected applying a typical questionnaire on the five-point Likert scale.

The CVR (content validity ratio) suggested by (Lawshe, 1975) is a linear transformation of a proportional level of agreement on how many 'experts' within a panel rate an item 'essential' considered (Taherdoost, 2016). To guarantee the validity of the scale items, we developed and evaluated a content validity index (CVI) to measure the degree to which the instrument covers the content that it should measure (Vesalainen, 2017). CVR and CVI indices were used to evaluate the content validity of the questionnaire. The reliability of the questionnaires was assessed by the Cronbach alpha reliability coefficient (Barutçu, 2007). (Ruekert, 1992) suggested that Cronbach's alpha value of 0.7 is considered adequate for internal consistency reliability. For relatively new scales, however, He suggested that an alpha value of 0.6 is acceptable (Ruekert, 1992). Srinivasan, on the other hand, argued that the alpha value of 0.5 or higher should be considered sufficient in exploratory research (Srinivasan, 1985). The SPSS Software (factor analysis) and Amos Software (structural equation modeling) were applied to analyze the collected data.

The scope of research includes SNOWA Corporation, while the external environment includes the oil, gas and petrochemical industry. The research period is between 23/10/2015 and 19/2/2017; the location of the research is in Tehran. One sample t-test and Amos software were applied for factor analysis and structural equation modeling respectively. One sample t-test measures whether a sample value varies from the hypothesized value or not. In other words, it measures whether the mean of a normally distributed population has a value specified in the null hypothesis. The one-sample t-test is used when we have a normal population or $\mathrm{n}>30$ while $\sigma$ is unknown (Riasi, 2015). In the first step of confirmatory factor analysis, the model's fitting is measured and in the second step, the path analysis is used to analyze the relationships among variables.

\section{Results}

Applying SPSS and AMOS22 software, data analysis was performed in three steps: 1- Recognition of data and preparation for the analysis. 2- Implementation of validation and reliability assessment. 3. Analysis of the conceptual model.

\subsection{Data Analysis}

Among 300 personnel of the corporation, $73 \%$ were male and $27 \%$ were female. In the study of education's level, $3 \%$ had $\mathrm{PhD}, 8 \%$ had a master's degree, $21 \%$ had a bachelor's degree and $69 \%$ had a high school diploma. $10 \%$ of the sample were working in the financial division, $13 \%$ were working in administrative and human resources division, 50\% were working in the production division, $7 \%$ were working in the warehouse division, $7 \%$ were working in the commercial division, $8 \%$ were working in the repair and maintenance division, $4 \%$ were working in the logistics 
division, and $2 \%$ were working in the IT division. In addition, $60 \%$ of employees had less than 5 years of professional experience, $25 \%$ had between 5 and 15 years of professional experience, $10 \%$ had between 15 and 25 years of professional experience, and $5 \%$ had more than 25 years of professional experience.

To determine the questionnaire reliability, test-retest and the Cronbach's alpha coefficient was done. In the test-retest method, within 10 days, the questionnaire filled by 20 persons who were similar to the study population. Then the Pearson-product moment correlation coefficient calculated and Cronbach's alpha for all the values were more than 0.70.

The validity of the questionnaires was assessed by the CVR and CVI. The questionnaire validity was checked by 14 experts in marketing and strategic fields and the content validity was evaluated by two indexes of CVR and CVI that were $>0.51$ and $>0.79$, respectively.

\subsection{Inferential Statistics}

In order to accept or reject the research's hypotheses, a one-sample t-test was conducted with the use of SPSS software. All the results are presented in the following table. In the first hypothesis, the value of $\mathrm{T}$ is equal to 7.4 which according to T-test 0.05 critical value at the $95 \%$ confidence level, the null hypothesis cannot be ruled out. Therefore, it can be concluded that there is a significant relationship between the marketing plan and marketing strategic planning. In the second hypothesis, the value of $\mathrm{T}$ is equal 8.9 which according to $\mathrm{T}$-test 0.05 critical value at the $95 \%$ confidence level, the null hypothesis cannot be ruled out. Thus, also there is a significant relationship between marketing mix and marketing strategic planning. In the third hypothesis, the value of $\mathrm{T}$ is equal 11.44 which according to T-test 0.05 critical value at the $95 \%$ confidence level, the null hypothesis cannot be ruled out. Thus, also there is a significant relationship between Identify and select target market and marketing strategic planning.

Table 1. Results of t-test

\begin{tabular}{lrrrrrr}
\hline & $\mathrm{t}$ & df & sig & Mean & Upper & Lower \\
\hline Marketing Plan & 7.4 & & 0.000 & 0.37 & 0.27 & 0.47 \\
Marketing Mix & 8.9 & & 0.000 & 0.43 & 0.34 & 0.53 \\
$\begin{array}{l}\text { Identify and select } \\
\text { target market }\end{array}$ & 11.44 & & 0.000 & 0.52 & 0.43 & 0.61 \\
\hline
\end{tabular}

The results of the statistical data confirm all the hypotheses of this research. All the independent variables have a strong relationship with Marketing strategic planning (the dependent variable).

\subsection{Structural Equation Modelling Results}

The path analysis is a developed method of multiple regression models (Wanta, 1994). In this analysis, the independent and dependent variables and the intermediary variables are analysed together. The path analysis results are shown as (Figure 2).

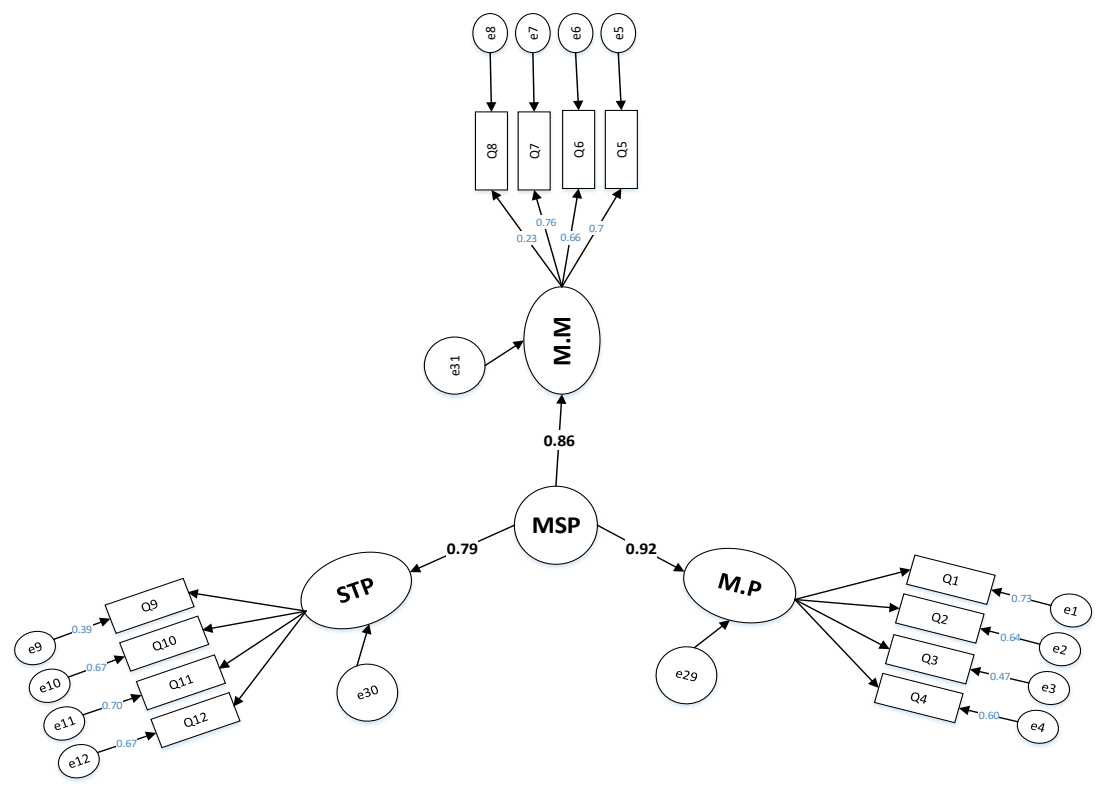

Figure 2. path analysis 


\subsection{Model Fitting Indices}

In this research CIM/df is equal to 2.38 , therefore, the model is suitable. In other words, the experimental model confirms the theoretical model. P-value is 0.06 , so the null hypothesis is confirmed in order to the lack of significant difference between the theoretical model and the data. RMSEA index is 0.056 , so the model and data are suitable.

Table 2. Indices

\begin{tabular}{lll}
\hline Index & Measure & Status \\
\hline CIM\df & 2.37 & Accept \\
RMSEA & 0.056 & Accept \\
P-value & 0.06 & Accept \\
\hline
\end{tabular}

As it is illustrated in the standardized regression weights table, marketing mix factor has the most influence on marketing strategic planning.

Table 3. Standardized Regression Weights

\begin{tabular}{lllr}
\hline & & & Estimate \\
\hline Marketing strategic planning & $\rightarrow$ & Marketing Plan & .857 \\
Marketing strategic planning & $-\rightarrow$ & Marketing Mix & .916 \\
Marketing strategic planning & $-\rightarrow$ & Identify and select target market & .792 \\
\hline
\end{tabular}

The following table shows the standardized influences of dependent factors. Marketing mix, marketing plan, Identify and select target market influences are direct and large-scale on the marketing strategic planning factor. The indirect effects of the factors are zero in order to lack an indirect path.

Table 4. Total standardized effects

\begin{tabular}{lc}
\hline & marketing strategic planning \\
\hline Marketing Plan & .857 \\
Marketing Mix & .916 \\
Identify and select target market & .792 \\
\hline
\end{tabular}

\section{Implementation in SNOWA Corporation}

Due to the importance of the mentioned factors, STP model has been used to identification, segmentation and target market selection. However, at the beginning of the STP process, the market identification stage has been added, due to the importance of identifying potential markets. Market identification, market segmentation, target market selection and positioning were conducted by the Market Research Committee.

\subsection{Market Identification}

In a market identification step, statistical databases and commercial information available on the Internet, such as www.comtarde.un.org website, which includes all commodity trade statistics and information that has been used in the world. This information indicates countries that are exporting expanded polystyrene and how much they import. The total number of importing countries is 141 .

\subsection{Market Segmentation}

Depending on the type of business, market segmentation is different. The business type of SNOWA corporation is B2B. Some of the indicators that SNOWA has used for market segmentation that include product application in different industries, product classification based on geographical area and product classification based on the importing growth for each country.

Based on the market research, more than $70 \%$ of these products are used in the building industry due to insulation. Based on geographic regions, the market is divided into six sections including North America, Latin America, Southeast Asia, South Asia, Middle East and Europe. Based on the import growth rates between 2011 to 2015, 65 countries have been positive growth, 91 countries with negative import growth and 40 countries without any change. Import growth trend by 2015 indicates that market growth has been decreasing for this product over the past year. In general, it can be said that the building and packaging industry is in recession. 


\subsection{Target Market}

According to the corporation's capabilities and external factors, target markets were selected. This selection was based on two major indicators including the annual volume of imports for each country and their import growth in the last five years. As well, other indicators such as intensity of competition, import tariffs and geographical distances were also taken into account. 21 countries were selected that have the closest distance to SNOWA corporation and based on annual imports, they also had a great potential for market entry.

\subsection{Market Positioning}

SNOWA corporation should determine its competitive position. They should clarify that they want to provide their products to all customers or a group of them. As well, they want to cover all customer needs or part of their needs.

Due to the capabilities of SNOWA corporation, there is no ability to meet all needs of customers. On the other hand, SNOWA does not have access to all customers, or serving to all customers has a lot of cost. It's better to meet all the needs of a group of customers that active in the building industry. SNOWA should invest more in hiring and training employees to deal with customers and meet their needs. The positioning statement of SNOWA corporation was determined as follows:

"We offer our products to construction workshops that require expanded polystyrene to produce ceiling blocks. Good price with good quality is our product features. Contrary to other competitors, we are committed to providing technical support from the beginning to the end".

\subsection{Marketing Mix}

To determine the appropriate marketing mix, a questionnaire was given to members of the marketing committee and asked them to identify marketing mixes that are most attractive to strategy formulation.

As you can see in the table below, the price mix is more important than others. It is considered as a very critical element. The price of the product should be set in such a way that buyers can pay and company can earn adequate profits. Therefore, formulating appropriate pricing policies for the products is very important. Afterwards, the product mix is more important especially quality. It is a seller's promise to deliver quality and satisfaction of buyer's expectations. It can be concluded that price and quality are the top priority for customers.

Table 5. Marketing Mix for SNOWA Corporation

\begin{tabular}{clcccc}
\hline \multirow{2}{*}{4 Ps } & \multicolumn{1}{c}{$\begin{array}{c}\text { Typical Marketing } \\
\text { Decisions }\end{array}$} & weight & $\begin{array}{c}\text { Attractiveness } \\
\text { Score }\end{array}$ & $\begin{array}{c}\text { Total Attractiveness } \\
\text { Score }\end{array}$ & $\begin{array}{c}\text { Total Attractiveness } \\
\text { Score for 4ps }\end{array}$ \\
\hline \multirow{5}{*}{ Promotion } & Advertising & 0.023 & 3 & 0.07 & \\
& Public relation & 0.039 & 4 & 0.157 & 0.667 \\
& Sales promotion & 0.067 & 3 & 0.2 & \\
& Direct marketing & 0.080 & 3 & 0.24 & \multirow{2}{*}{1.72} \\
\cline { 2 - 5 } Price & Price strategy & 0.21 & 4 & 0.82 & \\
& Discounts & 0.15 & 3 & 0.44 & 0.571 \\
& Payment terms & 0.09 & 5 & 0.46 & \\
& Distribution Channel & 0.12 & 3 & 0.36 & \\
\cline { 2 - 5 } Produce & Inventory & 0.05 & 3 & 0.135 & \\
& Transport and logistics & 0.03 & 3 & 0.076 & 0.909 \\
& Quality & 0.14 & 4 & 0.55 & \\
& Services & 0.04 & 4 & 0.033 & \\
\cline { 2 - 5 } & Branding & 0.01 & 3 & 0.078 & \\
& Packaging & 0.03 & 3 & 0.108 & \\
\hline
\end{tabular}

5.6 Developing and Implementing Marketing Plans

The marketing plan will provide significant benefits to organizations. SNOWA corporation intends to develop and implement marketing plans by relying on marketing mix. The viewpoint of different departments has been used in the 
preparation of these plans. The following table shows various marketing plans with a priority degree. In this table, it is the specified purpose of each plan and which department is responsible

Table 6. Marketing plan for SNOWA Corporation

\begin{tabular}{|c|c|c|c|}
\hline Priority & Marketing Plan & Future Result & Responsible \\
\hline 1 & $\begin{array}{l}\text { Product pricing } \\
\text { system reengineer }\end{array}$ & $\begin{array}{l}\text { Market penetration } \\
\text { Increasing sales volume and using of mass production } \\
\text { benefits } \\
\text { Reduce competitors market share } \\
\text { Provide strategic needs }\end{array}$ & $\begin{array}{l}\text { sales engineer } \\
\text { department }\end{array}$ \\
\hline 2 & Discount plan & $\begin{array}{l}\text { Sales growth } \\
\text { Encourage customers to buy more } \\
\text { Non-price competition }\end{array}$ & $\begin{array}{l}\text { sales engineer } \\
\text { department }\end{array}$ \\
\hline 3 & $\begin{array}{l}\text { Preparing a credit } \\
\text { sales plan }\end{array}$ & $\begin{array}{l}\text { Increasing sales } \\
\text { Increasing the number of customers } \\
\text { Attracting competitors' customers }\end{array}$ & Finance department \\
\hline 4 & $\begin{array}{l}\text { Product quality } \\
\text { Increase }\end{array}$ & $\begin{array}{l}\text { Raise customer satisfaction } \\
\text { Raise customer loyalty } \\
\text { Brand identity positioning } \\
\text { Costs reduce related to after-sales services }\end{array}$ & $\begin{array}{l}\text { Quality Control } \\
\text { department }\end{array}$ \\
\hline 5 & $\begin{array}{l}\text { Wholesale channel } \\
\text { plans }\end{array}$ & $\begin{array}{l}\text { Reduce advertising and promotion costs } \\
\text { Reduce distribution costs } \\
\text { Transferring warehousing costs to wholesalers } \\
\text { Simplifying sales processes }\end{array}$ & $\begin{array}{l}\text { Marketing } \\
\text { department }\end{array}$ \\
\hline
\end{tabular}

\section{Conclusion and Recommendation}

The purpose of this research was to identify the influence of marketing factors on marketing strategic planning in SNOWA Corporation. The findings make several contributions to the theoretical literature. The main contribution of this paper relative to the previous literature is a more detailed vision of the marketing strategic planning in sanction economic situation, providing information about the market circumstances that a company could face them. Knowledge of these factors, helps us to formulate strategies for companies much better which will experience economic sanctions. Also, this knowledge is useful for academics and for public and private managers responsible to formulate strategies and marketing plan. Other contributions are as follows:

First, the results of this research show that marketing factors positively affect marketing strategic planning as other studies stated (Anderson, 1982) (Cravens, 2006) (Aaker, 2010) (Tanner, 2015).

Second, findings show that Marketing Mix is more important than others. The literature review revealed a lack of academic research on the links between marketing factors and marketing strategic planning in the context of economic sanctions. Segmentation, targeting and positioning helps in strategic planning (Patil, 2017) and also is an antecedent of the marketing mix and the marketing plan (Londhe, 2014). Good marketing strategic planning should be based on the marketing plan.

Third, (Dreger, 2016) concluded that about one-third of sanctions have been successful, at least partially. (Caruso, 2003) derive that extensive and comprehensive sanctions have a large negative impact on bilateral trade. Our findings provide a more realistic understanding of how businesses react to economic sanctions in particular to differential impact across petrochemical industries. 


\subsection{Implications for Managers}

The findings of this research can potentially provide valuable insights to managers. The influences of implementing these factors in SNOWA Corporation were impressive. First, top managers of SNOWA Corporation acknowledged that these factors not only improved their viewpoint about all processes in different sections but also facilitated the tracking results. Second, firms need to respond properly to environmental conditions, taking into account marketing factors that can become valuable when managers to make a decision. these factors help SNOWA Corporation assess the market more accurately and consider all opportunities. Third, managers need to know about its competitive advantage in comparison to other competitors. Fourth, it's very important that corporate strategies meet customer needs. The results of this study bring senior executives a better understanding of customer needs

\subsection{Limitations}

There are some limitations that happened while performed research. First, there is always the possibility of losing relevant content from literature. Second, the scope of research is limited to SNOWA corporation not all the companies in Iran. Therefore, although this research is intended to be applied to all companies, the reality is that this research will reflect the influence of marketing factors on marketing strategic planning just in SNOWA Corporation. Third, the effect of situational factors has not been considered in the current investigation, that may have an impact on dependence variable. Fourth, this study is also being conducted during a sanction period. Therefore, results will be in response to this conditions.

\subsection{Future Research}

As a matter of fact, every industry or business has unique characteristics. It is recommended to implement these factors in various industries and businesses such as home appliances, automobile, etc. Also, this paper only has focused on marketing factors, while there would exist other important factors. Therefore, further work is needed to identify other factors, also, which one is more important? How these factors influence marketing strategic planning? Are there any relations among them? How could managers control strategies implementation? In the future, this research can be carried out in other countries and industries. Future studies may use other methods such as structural equation modeling (SEM), that will help more in model validation. Besides, because of the small sample size used for this study and the low response rate, a similar study on a larger scale should be carried out to investigate the validity of the results more and more.

\section{References}

Aaker, D. A. (2010). Strategic market management: global perspectives. John Wiley \& Sons.

Anderson, P. F. (1982). Marketing, strategic planning and the theory of the firm. The Journal of Marketing, 15-26. https://doi.org/10.1177/002224298204600203

Andreasen, A. R. (2008). Strategic marketing for nonprofit organizations. Upper Saddle River, NJ: Pearson/Prentice Hall.

Barutçu, S. (2007). Attitudes towards mobile marketing tools: A study of Turkish consumers. Journal of Targeting, Measurement and Analysis for Marketing, 26-38. https://doi.org/10.1057/palgrave.jt.5750061

Burns, A. C. (2014). Marketing research (Vol. 7). Harlow: Pearson.

Cravens, D. W. (2006). Strategic marketing (Vol. 7). New York, NY: McGraw-Hill.

Fernando, Y. M. (2012). New marketing definition: a future agenda for low cost carrier airlines in Indonesia. Business Strategy Series, 13(1), 31-40. https://doi.org/10.1108/17515631211194607

Haugum, M. H. (2017). The Role of Marketing in Local Food Network. International Journal on Food System Dynamics, 1-13.

Hill, M. E. (2012). Marketing strategy: the thinking involved. Sage.

Huang, R. (2014). How brand awareness relates to market outcome, brand equity, and the marketing mix. In Fashion Branding and Consumer Behaviors. Springer, 113-132. https://doi.org/10.1007/978-1-4939-0277-4_8

Kotler, P. (2010). Principles of marketing. Pearson education.

Kumar, V. R. (2016). Assessing the Influence of Stakeholders on Sustainability Marketing Strategy of Indian Companies. SAGE Open. https://doi.org/10.1177/2158244016667991

Lantos, G. P. (2015). Consumer behavior in action: Real-life applications for marketing managers. Routledge. https://doi.org/10.4324/9781315705439 
Lawshe, C. H. (1975). A quantitative approach to content validity. Personnel psychology, 563-575. https://doi.org/10.1111/j.1744-6570.1975.tb01393.x

Levy, M. W. (2012). Retailing management (Vol. 6). New York: McGraw-Hill/Irwin.

Londhe, B. R. (2014). Marketing mix for next generation marketing. Procedia Economics and Finance, 335-340. https://doi.org/10.1016/S2212-5671(14)00201-9

Martin, D. (2013). Marketing without marketing. The Conference Board Review, (pp. 70-71).

McDONALD, M. A. (2016). Strategic marketing planning: theory and practice. In The marketing book. Routledge.

Muhamad, R. M. (2012). Segmentation and brand positioning for Islamic financial services. European Journal of Marketing, 46(7/8), 900-921. https://doi.org/10.1108/03090561211230061

Patil, D. D. (2017). Marketing-Mix For Strategy Building. Marketing, 4.

Perreault, W. D. (2011). Basic marketing: A marketing strategy planning approach. New York, NY: McGraw-Hill Irwin.

Petersen, J. A. (2015). Marketing communication strategies and consumer financial decision making: The role of national culture. Journal of Marketing, 44-63. https://doi.org/10.1509/jm.13.0479

Proctor, T. (2014). Strategic marketing: an introduction. Routledge. https://doi.org/10.4324/9781315824222

Riasi, A. (2015). Effects of online marketing on Iranian ecotourism industry: Economic, sociological, and cultural aspects. Management Science Letters, 915-926. https://doi.org/10.5267/j.msl.2015.8.005

Ruekert, R. W. (1992). Developing a market orientation: an organizational strategy perspective. International journal of research in marketing, 225-245. https://doi.org/10.1016/0167-8116(92)90019-H

Srinivasan, A. (1985). Alternative measures of system effectiveness: associations and implications. MIS quarterly, 243-253. https://doi.org/10.2307/248951

Taherdoost, H. (2016). Validity and Reliability of the Res...earch Instrument; How to Test the Validation of a Questionnaire/Survey in a Research. International Journal of Academic Research in Management, 28-36.

Tanner, J. (2015). Principles of marketing. University of Minnesota Libraries Publishing.

Varadarajan, R. (2010). Strategic marketing and marketing strategy: domain, definition, fundamental issues and foundational premises. Journal of the Academy of Marketing Science, 38(2), 119-140. https://doi.org/10.1007/s11747-009-0176-7

Vesalainen, J. R. (2017). Boundary Spanning and the Art of Persuasion. In Practices for Network Management. Palgrave Macmillan, Cham, 91-103. https://doi.org/10.1007/978-3-319-49649-8_7

Wanta, W. (1994). The effects of credibility, reliance, and exposure on media agenda-setting: A path analysis model. Journalism Quarterly, 90-98. https://doi.org/10.1177/107769909407100109

West, D. C. (2015). Strategic marketing: creating competitive advantage. USA: Oxford University Press.

Westwood, J. (2013). How to write a marketing plan. Kogan Page Publishers.

\section{Copyrights}

Copyright for this article is retained by the author(s), with first publication rights granted to the journal.

This is an open-access article distributed under the terms and conditions of the Creative Commons Attribution license which permits unrestricted use, distribution, and reproduction in any medium, provided the original work is properly cited. 